\title{
MENINGKATKAN HASIL BELAJAR KELAS VII - C SOAL CERITA METEMATIKA MELALUI PENGCUNAAN BAHAN MANIPULATIF SISWA TUNAGRAHITA RINGAN DI SMPLB KERATON MARTAPURA KABUPATEN BANJAR
}

\begin{abstract}
Sugiyana
Abstrak

Meski matematika dipandang sulit, namun semua orang harus mempelajarinya karena merupakan sarana untuk memecahkan masalah kehidupan sehari-hari, Pembelajaran soal cerita (word/story problem) dalam matematika dapat digunakan sebagai wahana untuk melatih Siswa Tunagrahita Ringan dalam menyelesaikan masalah. Namun berdasarkan pengamatan siswa Kelas VII - C di SMPLB Keraton Martapura masih kesulitan dalam mempelajari soal cerita. Penggunaan metode dan media ajar yang sesuai tahap perkembangan kejiwaan dan penggunaan media belajar konkret, dapat mengatasi kesulitan dalam mengerjakan soal cerita. Penelitian ini bertujuan untuk mengetahui peningkatan pembelajaran soal cerita matematika dengan menggunakan bahan manipulatif.

Jenis penelitian ini adalah penelitian tindakan kelas (PTK). Subjek dalam penelitian ini adalah siswa Kelas VII - C di SMPLB Keraton Martapura yang berjumlah 8 orang terdiri dari 4 orang laki-laki dan 4 orang perempuan. Jenis data yang disajikan dalam penelitian ini adalah data kuantitatif berupa nilai efektivitas guru mengajar, dan aktivitas siswa belajar. Analisis hasil tes digunakan indikator ketuntasan belajar berupa nilai KKM Matematika Kelas VII - C di SMPLB Keraton Martapura 6,60 sebanyak $80 \%$ dari keseluruhan siswa.

Hasil penelitian dilihat dari rata-rata kelas tes hasil belajar yang diperoleh siswa pada masing-masing pertemuan yakni pertemuan $1=60.45$, pertemuan $2=68.41$, pertemuan $3=69.31$, pertemuan $4=69.78$, dan pertemuan $5=73.4$ yang berada di atas nilai rata-rata ketuntasan pembelajaran Matematika yakni 70,0.
\end{abstract}

Kata Kunci: soal cerita matematika dan bahan manipulative. 
Sugiyana

\section{Pendahuluan}

Anak Luar Biasa/ALB yang juga dikenal dengan istilah Anak Berkebutuhan Khusus / ABK adalah anak-anak yang mengalami kelainan khusus baik fisik, mental, maupun sosialnya. Anak dengan kelainan khusus mempunyai hendaya (hambatan) perkembangan memerlukan layanan pendidikan khusus. Sesuai dengan Undang-Undang Republik Indonesia No. 20 ayat (1). Dinyatakan bahwa "Pendidikan khusus merupakan pendidikan bagi peserta didik yang memiliki tingkat kesulitan dalam mengikuti proses pembelajaran karena kelainan fisik, emosional, mental, sosial, dan atau memiliki potensi kecerdasan dan bakat istimewa.” (Bandi Delphie, 2007 : 55).

Pembelajaran untuk anak berkebutuhan khusus (student with special needs) membutuhkan suatu pola tersendiri sesuai dengan kebutuhannya masing-masing, yang berbeda antara satu dan lainnya. Dalam penyusunan program pembelajaran untuk setiap bidang studi hendaknya guru kelas sudah memiliki data pribadi setiap peserta didik. Data pribadi berkaitan dengan karakteristik spesifik, kemampuan dan kelemahannya, kompetensi yang dimiliki dan tingkat perkembangannya.

Salah satu jenis anak berkebutuhan khusus adalah anak tunagrahita atau anak dengan gangguan intelektual rendah. Seorang dikatakan tunagrahita apabila memiliki tiga faktor, yaitu: (1) keterhambatan fungsi kecerdasan secara umum atau di bawah rata-rata, (2) ketidakmampuan dalam perilaku adaptif, dan (3) terjadi pada masa perkembangan sampai usia 18 tahun. Para ahli Indonesia menggunakan klasifikasi: Tunagrahita Ringan IQ nya 50 - 70, Tunagrahita Sedang IQnya 30 - 50, dan Tunagrahita berat dan sangat berat IQ nya di bawah 30 (Munawir Yusup, 2011).

Pendidikan Matematika merupakan ilmu universal yang mendasari perkembangan teknologi modern, mempunyai peran penting dalam berbagai disiplin dan memajukan daya pikir manusia. Untuk menguasai dan menciptakan teknologi di masa depan diperlukan penguasaan 
Meningkatkan Hasil Belajar Kelas VII - C Soal Cerita Metematika Melalui Penggunaan Bahan Manipulatif Siswa Tunagrahita Ringan Di SMPLB Keraton Martapura Kabupaten Banjar

matematika yang kuat sejak dini. Mata pelajaran matematika perlu diberikan kepada semua peserta didik mulai dari sekolah dasar untuk membekali peserta didik dengan kemampuan berpikir logis, analitis, sistematis, kritis, dan kreatif, serta kemampuan bekerjasama. Kompetensi tersebut diperlukan agar peserta didik dapat memiliki kemampuan memperoleh, mengelola, dan memanfaatkan informasi untuk bertahan hidup pada keadaan yang selalu berubah, tidak pasti, dan kompetitif.

Soal cerita (word/story problem) identik dengan suatu permasalahan matematika yang harus dipecahkan. Pemecahan masalah pada dasarnya adalah proses yang ditempuh seseorang untuk menyelesaikan masalah baginya. Ada suatu model yang dijadikan dasar proses pemecahan masalah yang diusulkan oleh George Polya yaitu model empat tahap yaitu memahami masalah, membuat rencana untuk menyelesaikannya, melaksanakan rencana yang dibuat pada langkah kedua, dan memeriksa ulang jawaban yang diperoleh.

Pembelajaran soal cerita (word/story problem) dapat digunakan sebagai wahana untuk melatih siswa SLB-C dalam menyelesaikan masalah. Namun berdasarkan pengamatan bahwa di SMPLB-C Keraton kelas VII masih kesulitan dalam mempelajari soal cerita. Di dalam mempelajari topik soal cerita, walaupun siswa tunagrahita sudah berulangkali dijelaskan ternyata masih banyak yang belum dapat mengerjakan dengan benar.

Cara yang dapat dilakukan untuk mengatasi kesulitan siswa dalam mengerjakan soal cerita, diperlukan adanya upaya guru dalam menggunakan metode mengajar dan media pembelajaran yang dapat memenuhi tuntutan kebutuhan siswa dalam belajar sesuai dengan tahap perkembangan kejiwaannya. Guru dituntut untuk menggunakan metode yang bervariasi tidak hanya ceramah saja, tetapi juga metode-metode lainnya seperti metode pembelajaran yang lebih menekankan pada pembelajaran aktif, kreatif, efektif dan menyenangkan. Selain itu guru juga 
dituntut untuk menggunakan media pembelajaran yang kongkrit yaitu berupa bahan manipulatif.

\section{Metode Penelitian}

\section{Pendekatan dan Jenis Penelitian}

Penelitian ini menggunakan pendekatan tindakan sekolah yaitu bentuk pembelajaran yang bersifat reflektif untuk memperbaiki kondisi pembelajaran dan meningkatkan kemantapan rasional dari tindakan melaksanakan tugas dengan proses pengkajian berdaur, yaitu merencanakan, melakukan tindakan, mengamati, dan refleksi (Winardi, 2004 : 6 ). Jenis penelitian yang dugunakan dalam penelitian ini adalah Penelitian Tindakan Kelas.

Langkah-langkah penelitian tindakan ini dapat digambarkan sebagai berikut :

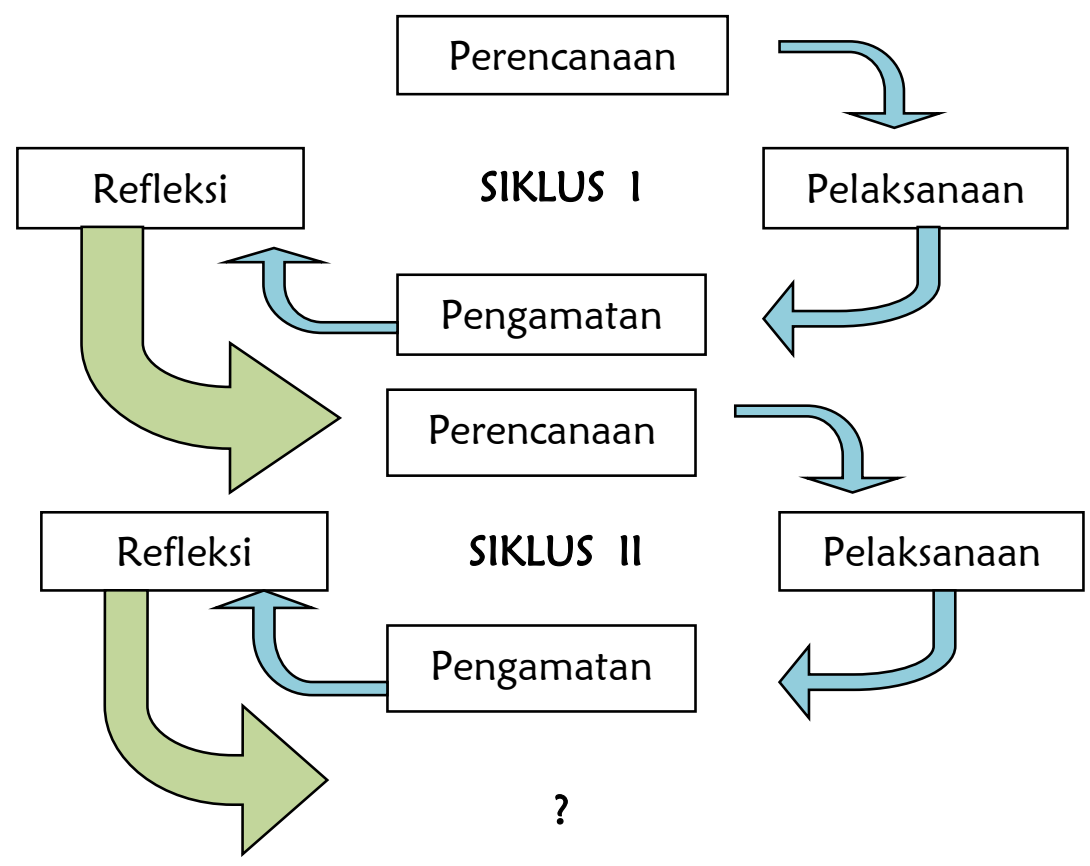

Gambar 1 . Langkah-langkah PTK (Direktorat Tendik, 2008)

\section{Setting Penelitian}

Penelitian tindakan kelas membahas tentang pelaksanaan kegiatan belajar mengajar untuk meningkatkan hasil belajar soal ceritera. Setting penelitiaan ini adalah keadaan kelas dan siswa saat dilaksanakannya proses 
Meningkatkan Hasil Belajar Kelas VII - C Soal Cerita Metematika Melalui Penggunaan Bahan Manipulatif Siswa Tunagrahita Ringan Di SMPLB Keraton Martapura Kabupaten Banjar

belajar mengajar yang dilaksanakan di kelas VII - C SMPLB Keraton Martapura berjumlah 8 dengan rincian laki-laki 4 orang dan perempuan 4 orang.

\section{Faktor Yang Diteliti}

Untuk menjawab pertanyaan yang dirumuskan dalam penelitian, ada beberapa faktor yang akan di teliti yaitu : (1) Faktor Siswa; Pemahaman konsep matematika sesuai materi yang disampaikan dalam proses pembelajaran siswa kelas VII - C SMPLB Keraton Martapura terhadap soal cerita matematika dengan penggunaan bahan manipulatif. (2) Faktor Guru; Faktor guru dilihat dari sisi persiapan pembelajaran serta strategi pembelajaran yang diterapkan oleh guru dalam menggunakan bahan manipulatif berupa persegi satuan yang dipotong-potong. (3) Faktor Hasil Belajar ; Meningkatnya hasil belajar soal cerita matematika dengan indikator meningkatnya hasil belajar siswa

\section{Skenario Tindakan}

Sebagaimana prosedur penelitian tindakan kelas, maka dilaksanakanlah penelitian tindakan kelas ini dengan langkah-langkah (a) perencanaan, (b) pelaksanaan tindakan , (c) observasi dan evaluasi dan (d) refleksi

\section{Data dan Cara Pengumpulan Data}

a. Data ; Jenis data yang disajikan dalam penelitian ini adalah data kuantitatif dan data kualitatif. Data kuantitatif berupa nilai tes siswa, sedangkan data kualitatif berupa observasi kegiatan siswa dan guru.

b. Cara Pengumpulan Data; Data digali dan dikumpulkan dari kegiatan guru mengajar, kegiatan belajar siswa dan hasil tes akhir pada masing-masing pertemuan 
Perhitungan persentasi aktifitas guru dalam kegiatan penyusunan rancangan pembelajaran dengan menggunakan rumus sebagai berikut :

$$
P=\frac{f}{N} \times 100 \%
$$

Keterangan:

$$
\begin{array}{ll}
\mathrm{P} & =\text { angka persentasi } \\
\mathrm{f} & =\text { frekuensi } \\
\mathrm{N} & =\text { number of cases (jumlah frekuensi) }
\end{array}
$$

(Sudijono : 2003)

Hasil persentasi dapat dikatagorikan sebagai berikut :

$$
\begin{array}{ll}
85 \%-100 \% & =\text { baik sekali } \\
70 \%-84 \% & =\text { baik } \\
55 \%-69 \% & =\text { cukup } \\
40 \%-54 \% & =\text { kurang } \\
0 \%-39 \% & =\text { kurang sekali }
\end{array}
$$

Perhitungan hasil penyusunan rancangan pembelajaran dan simulasi dengan menggunakan rumus sebagai berikut :

$$
P=\frac{j r}{N i} \times 100 \%
$$

Keterangan:

$$
\begin{array}{ll}
\mathrm{P} & =\text { angka persentasi } \\
\mathrm{jr} & =\text { Jumlah nilai riil } \\
\mathrm{Ni} & =\text { Jumlah nilai ideal }
\end{array}
$$

Hasil persentasi proses belajar mengajar sebagai berikut :

$$
\begin{array}{ll}
76 \% \text { s.d. } 100 \% & =\text { baik sekali } \\
56 \% \text { s.d. } 75 \% & =\text { baik } \\
26 \% \text { s.d. } 55 \% & =\text { cukup } \\
0 \% & \text { s.d. } 25 \%=\text { kurang }
\end{array}
$$


Meningkatkan Hasil Belajar Kelas VII - C Soal Cerita Metematika Melalui Penggunaan Bahan Manipulatif Siswa Tunagrahita Ringan Di SMPLB Keraton Martapura Kabupaten Banjar

Hasil penilaian administrasi pembelajaran sebagai berikut :

$\begin{array}{rll}101 & \text { s.d. } 125 & =\text { baik sekali } \\ 76 & \text { s.d. } 100 & =\text { baik } \\ 75 & \text { s.d. } \quad 51 & =\text { cukup } \\ 26 & \text { s.d. } \quad 50 & =\text { kurang } \\ 0 & \text { s.d. } 25 & =\text { tidak ada }\end{array}$

\section{Indikator Keberhasilan}

Penelitian ini dianggap berhasil jika hasil belajar siswa melalui tes tertulis tentang pengerjaan soal cerita pada akhir proses pembelajaran mencapai kualifikasi baik yaitu nilai individu anak mencapai nilai KKM (Kriteria Ketuntasan Minimal) di kelas VII SMPLB Keratom Martapura dan dinyatakan paham jika seluruh siswa kelas VII SMPLB Ksraton Martapura mendapatkan nilai diatas KKM sejumlah $80 \%$

\section{Hasil dan Pembahasan}

\section{Kondisi Sekolah}

Penelitian kelas ini dilaksanakan di kelas VII SMPLB Keraton Martapura yang berjumlah 8 orang terdiri dari 4 orang siswa laki-laki dan 4 orang siswa perempuan. SMPLB Keraton terletak Jl. Menteri Empat No. 25 Rt. 12/Rw 5 Kelurahan Sungai Paring Kecamatan Martapura Kota Martapura Kabupaten Banjar.

Permasalahan dalam penelitian ini adalah rendahnya nilai matematika siswa kelas VII SMPLB Keraton Martapura terutama dalam menjawab soal cerita pada materi keliling dan luas bangun persegi panjang. Guru dalam hal ini peneliti berusaha melakukan pembelajaran dengan menggunakan bahan ajar / alat manipulatif agar dapat meningkatkan hasil belajar dalam menjawab soal cerita bagi siswa kelas VII SMPLB Keraton Martapura Kabupaten Banjar. 


\section{Kegiatan Siklus I}

\section{a. Perencanaan}

Peneliti pada tahap perencanaan atau persiapan adalah pada tanggal, 23 September 2014, peneliti melakukan pengamatan khusus saat pembelajaran Matematika maupun wawancara dengan guru dan wawancara dengan siswa. Pengamatan saat proses pembelajaran dilakukan sebanyak tiga kali.

Kegiatan yang dilakukan untuk melaksanakan pembelajaran pada pertemuan 1 ini sebagai berikut: (a) Menyusun RPP Matametika Standar Kompetensi : 5. Menghitung keliling, luas persegi dan persegi panjang serta penggunaannya dalam pemecahan masalah. Kompentensi Dasar 5.3 Menyelesaikan masalah yang berkaitan dengan keliling, luas persegi dan pesegi panjang di kelas VII SMPLB Keraton Martapura pada semester 2 Tahun Pelajaran 2013/2014. (b) Menyiapkan bahan dan media berupa kertas berpetak. (c) Menyiapkan instrumen penilaian sebagai indikator. (c)Membuat format oberservasi untuk mengamati kegiatan guru dan siswa dalam pembelajaran.

\section{b. Pelaksanaan Tindakan Kelas}

Pelaksanaan tindakan kelas pada pertemuan 1 dengan langkahlangkah sebagai berikut: (a) Pra KBM ( \pm 5 menit) yakni kesiapan alat dan bahan pembelajaran, dan mengkondisikan kelas yang siap belajar (b) Kegiatan Awal ( \pm 5 menit) yakni, (a) menanyakan kehadiran anak, mengadakan apersepsi, dan memberitahukan tujuan/indikator pembelajaran (a) Kegiatan Inti ( \pm 40 menit) yakni (b) guru memberikan penjelasan materi tentang menggambar bangun persegi panjang dan menghitung keliling persegi panjang dengan petak satuan soal cerita berkaitan dengan keliling bangun persegi panjang. (c) siswa memperhatikan guru menjelaskan materi. dan (d) guru memberikan kesempatan siswa untuk bertanya merefleksi pelajaran dan mencatat hal-hal penting. 
Meningkatkan Hasil Belajar Kelas VII - C Soal Cerita Metematika Melalui Penggunaan Bahan Manipulatif Siswa Tunagrahita Ringan Di SMPLB Keraton Martapura Kabupaten Banjar

\section{c. Observasi}

Observasi yang dilakukan pada siklus I terhadap pada pertemuan 1 adalah melihat kegiatan guru mengajar, aktivitas siswa belajar dan tes hasil belajar berupa hasil jawaban siswa terhadap soal yang diberikan diakhir pembelajaran. Hasil observasi kegiatan belajar siswa pada pertemuan 2 ini dilakukan dengan melihat aktivitas belajar siswa dan tes hasil belajar berupa hasil jawaban siswa terhadap soal yang diberikan diakhir pembelajaran.

Hasil observasi kegiatan belajar siswa pada pertemuan 3 ini dilakukan dengan melihat aktivitas belajar siswa dan tes hasil belajar berupa hasil jawaban siswa terhadap soal yang diberikan diakhir pembelajaran. Hasil observasi berupa aktivitas siswa disajikan dalam tabel berikut ini

Tabel 1 Hasil Observasi Aktivitas Belajar Anak siklus 1

\begin{tabular}{|l|l|c|c|c|c|c|c|}
\hline \multirow{2}{*}{ No } & \multirow{2}{*}{ Nama siswa } & \multicolumn{2}{|c|}{ Aspek penilaian } & \multirow{2}{*}{ Jmlh } & Rata- & \multirow{2}{*}{ Kata } & Kriteria \\
\cline { 3 - 7 } & & A & B & C & & Rata & \\
\hline 1 & Achmad & 50 & 50 & 60 & 160 & 53,3 & Cukup \\
\hline 2 & M. Rizali Manusama & 50 & 50 & 60 & 160 & 53,3 & Cukup \\
\hline 3 & Amania Nabila & 40 & 50 & 60 & 150 & 50,0 & Kurang \\
\hline 4 & Fajari Sultan & 60 & 60 & 60 & 180 & 60,0 & Baik \\
\hline 5 & M. Sannan Khairuzzaman & 50 & 50 & 60 & 160 & 53,3 & Cukup \\
\hline 6 & M. Fikri & 60 & 40 & 50 & 150 & 50,0 & Kurang \\
\hline 7 & Siri Mahmudi & 60 & 60 & 50 & 170 & 56,7 & Baik \\
\hline 8 & M. Reza Fahlevi & 60 & 50 & 50 & 160 & 53,3 & Cukup \\
\hline & JUMLAH & 1110 & 1100 & 1140 & 3350 & 50,79 & Cukup \\
\hline
\end{tabular}

Sesuai dengan tabel 1 menunjukkan bahwa dari penilaian dan pengamatan terhadap hasil observasi aktivitas belajar anak dari kedelapan siswa yang "baik" ada 2 orang, sedangkan yang menunjukkan presentasi "cukup" 4 orang dan yang prsesntasi kurang 
ada 2 orang. Rara-rata aktifitas belajar siswa secara keseluruhan dengan prosentasi 50,79 dengan kategori "cukup”

Selanjutnya dilakukan observasi terhadap tes hasil belajar berupa hasil jawaban siswa terhadap soal yang diberikan diakhir pembelajaran dapat dilihat pada tabel 2

Tabel 2 Daftar Nilai Tes Hasil Belajar Siswa pada siklus 1

\begin{tabular}{|l|c|c|c|c|}
\hline \multirow{2}{*}{ No } & \multirow{2}{*}{ Rentang Nilai } & \multicolumn{2}{|c|}{ Pertemuan 3 } & \multirow{2}{*}{ Keterangan } \\
\cline { 3 - 4 } & & $F$ & $\%$ & \\
\hline 1 & $40-49$ & 0 & 0 & \\
\hline 2 & $50-59$ & 1 & 4.55 & \\
\hline 3 & $60-69$ & 5 & 22.72 & \\
\hline 4 & $70-79$ & 11 & 50 & \\
\hline 5 & $80-89$ & 1 & 4,55 & \\
\hline 6 & $90-99$ & 2 & 9.09 & \\
\hline 7 & $100-109$ & 2 & 9.09 & \\
\hline & JUMLAH & 22 & 100 & \\
\hline & RATA - RATA & \multicolumn{2}{|c|}{69.31} & \\
\hline
\end{tabular}

\section{d. Refleksi}

Berdasarkan hasil observasi melalui instrumen atau format observasi tentang kegiatan pembelajaran dan kegiatan siswa serta tes hasil belajar siswa dalam pertemuan ke -1 , ke -2 , dan ke -3 pada Siklus I, maka dapat direfleksikan sebagai berikut:

1) Kegiatan yang dilaksanakan guru pada pertemuan 1 dan 2 belum maksimal, masih ada beberapa aspek pembelajaran yang belum dilaksanakan secara maksimal sesuai dengan perencanaan. Aspek pembelajaran baru dilaksanakan sekitar $75 \%$, pada pertemuan 1 ini aspek yang belum dilaksanakan adalah belum disampaikannya SK / KD dan tujuan pembelajaran/indikator, belum dikuasainya materi ajar oleh guru, belum dilibatkan dan belum diberi kesempatan siswa dalam penggunaan bahan manipulatif. Ketika pertemuan 2 sudah 
Meningkatkan Hasil Belajar Kelas VII - C Soal Cerita Metematika Melalui

Penggunaan Bahan Manipulatif Siswa Tunagrahita Ringan Di SMPLB Keraton Martapura Kabupaten Banjar

terjadi peningkatan yakni sudah mencapai $80 \%$ pelaksanaan. Meskipun begitu aspek penyampaian SK/KD dan tujuan pembelajaran belum dilaksanakan, serta pelibatan dan pemberian kesempatan menggunakan bahan manipulatif belum dilakukan guru. Selanjutnya untuk pertemuan 3 semua aspek pembelajaran sudah dilaksanakan 100\%, namun belum memperoleh predikat baik atau sangat baik. Hal itu karena baru memperoleh skor 59 dan jika dikonversikan pada pedoman penskoran baru mendapat predikat cukup baik. Karenanya untuk kegiatan pembelajaran guru akan coba ditingkatkan pada siklus II.

2) Aktivitas siswa saat belajar pada pertemuan 1, 2, dan 3 menunjukkan adanya peningkatan yang cukup siginifikan. Pada pertemuan 1 memperoleh nilai 40,27 meningkat menjadi 42,87 pada pertemuan 2 , sedangkan pada pertemuan 3 berubah menjadi 50,79 namun belum mencapai hasil maksimal. Hal ini diduga karena guru belum betul-betul melibatkan dan memberi kesempatan kepada siswa untuk menggunakan bahan manipulatif. Oleh karena itu pada siklus II aspek penggunaan bahan manipulatif oleh siswa akan lebih ditingkatkan.

3) Hasil belajar siswa pada pertemuan 1, 2, dan 3 belum tuntas karena belum sesuai dengan indikator ketuntasan belajar Matematika yakni 70. Pada pertemuan 1 siswa kelas VII SMPLB Keraton Martapura hanya memperoleh rata-rata kelas 60.45, sedangkan pada pertemuan 2 hanya memperoleh nilai rata-rata kelas 68.41, dan pertemuan 3 memperoleh nilai 69.31. Anak yang belum tuntas pada pertemuan 1 dengan rentang nilai 40 - 49 sebanyak 5 orang (22.72\%), rentang nilai 50 - 59 sebanyak 3 anak (13.63\%), sedangkan pada rentang nilai 60 - 69 sebanyak 8 orang (36.36\%). Sehingga jika dikalkulasi anak yang tidak tuntas pada pertemuan 1

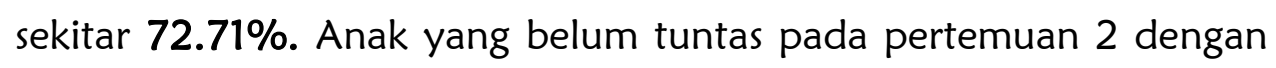


rentang nilai 40 - 49 sebanyak 1 orang (4.55\%), rentang nilai 50 59 sebanyak 1 orang (4.55\%), sedangkan pada rentang nilai 60 - 69 sebanyak 9 orang (40.9\%). Sehingga jika dikalkulasi anak yang tidak tuntas pada pertemuan 2 sekitar 50 \%. Sedangkan anak yang belum tuntas pada pertemuan 3 sudah mulai berkurang, namun masih ada anak yang memperoleh nilai pada rentangan 50 - 59 sebanyak 1 orang (4.55\%), dan rentangan 60 - 69 sebanyak 5 orang (22.72 \%). Sehingga jika dikalkulasi sekitar $27.27 \%$.

Hal ini memang menunjukkan sudah adanya peningkatan, namun belum signifikan, diharapkan dengan pertemuan 1, 2 dan 3 dapat memberikan kemampuan dasar pada siswa untuk dapat menggunakan bahan manipulatif dalam menjawab soal cerita pada siklus II.

\section{Kegiatan Siklus II}

\section{a. Perencanaan}

Penelitian pada siklus II sama dengan kegiatan perencanaan pada siklus I yaitu tahap perencanaan atau persiapan. Kegiatan yang dilakukan untuk melaksanakan pembelajaran pada pertemuan 1 ini sebagai berikut: (a) Menyusun RPP Matametika Standar Kompetensi : 5. Menghitung keliling, luas persegi dan persegi panjang serta penggunaannya dalam pemecahan masalah. Kompentensi Dasar 5.3 Menyelesaikan masalah yang berkaitan dengan keliling, luas persegi dan pesegi panjang di kelas VII SMPLB Keraton Martapura pada semester 2 Tahun Pelajaran 2013/2014. (b) Menyiapkan bahan dan media berupa kertas berpetak. Menyiapkan instrumen penilaian sebagai indikator. (c) Membuat format oberservasi untuk mengamati kegiatan guru dan siswa dalam pembelajaran.

\section{b. Pelaksanaan Tindakan Kelas}

Pelaksanaan tindakan kelas pada pertemuan 1 dengan langkah-langkah sebagai berikut: (a) Pra KBM ( \pm 5 menit) yakni 
Meningkatkan Hasil Belajar Kelas VII - C Soal Cerita Metematika Melalui Penggunaan Bahan Manipulatif Siswa Tunagrahita Ringan Di SMPLB Keraton Martapura Kabupaten Banjar

kesiapan alat dan bahan pembelajaran, dan mengkondisikan kelas yang siap belajar (b) Kegiatan Awal ( \pm 5 menit) yakni, (a) menanyakan kehadiran anak, mengadakan apersepsi, dan memberitahukan tujuan / indikator pembelajaran (a) Kegiatan Inti ( \pm 40 menit) yakni (b) guru memberikan penjelasan materi tentang menggambar bangun persegi panjang dan menghitung keliling persegi panjang dengan petak satuan soal cerita berkaitan dengan keliling bangun persegi panjang. (c) siswa memperhatikan guru menjelaskan materi. dan (d) guru memberikan kesempatan siswa untuk bertanya merefleksi pelajaran dan mencatat hal-hal penting.

c. Observasi

Observasi yang dilakukan pada siklus II terhadap pada pertemuan adalah melihat kegiatan guru mengajar, aktivitas siswa belajar dan tes hasil belajar berupa hasil jawaban siswa terhadap soal yang diberikan diakhir pembelajaran. Hasil observasi kegiatan belajar siswa pada pertemuan 5 ini dilakukan dengan melihat aktivitas belajar siswa dan tes hasil belajar berupa hasil jawaban siswa terhadap soal yang diberikan diakhir pembelajaran. Hasil observasi berupa aktivitas siswa disajikan dalam tabel 3 berikut ini.

Tabel 3 Hasil Observasi Aktivitas Belajar Anak Pertemuan 5 siklus II

\begin{tabular}{|l|l|l|c|c|c|c|c|}
\hline \multirow{2}{*}{ No } & \multirow{2}{*}{ Nama siswa } & \multicolumn{3}{|c|}{ Aspek Penilaian } & \multirow{2}{*}{ Jmlh } & $\begin{array}{c}\text { Rata } \\
\text { Rata }\end{array}$ & Kriteria \\
\cline { 3 - 6 } & & A & B & C & & 76,7 & Sangat Baik \\
\hline 1 & Achmad & 80 & 80 & 70 & 230 & 70 & \\
\hline 2 & M. Rizali M & 70 & 80 & 80 & 230 & 76,7 & Sangat Baik \\
\hline 3 & Amania Nabila & 70 & 80 & 80 & 230 & 76,7 & Sangat Baik \\
\hline 4 & Fajari Sultan & 70 & 80 & 80 & 230 & 76,7 & Sangat Baik \\
\hline 5 & M. Sannan K & 70 & 80 & 80 & 230 & 76,7 & Sangat Baik \\
\hline 6 & M. Fikri & 80 & 80 & 70 & 230 & 76,7 & Sangat Baik \\
\hline 7 & Siri Mahmudi & 70 & 70 & 80 & 220 & 73,3 & Sangat Baik \\
\hline 8 & M. Reza Fahlevi & 80 & 70 & 70 & 220 & 73,3 & Sangat Baik \\
\hline
\end{tabular}




\begin{tabular}{|l|l|l|l|l|l|l|l|}
\hline & JUMLAH & 1610 & 1680 & 1650 & 4940 & 74.85 & Sangat Baik \\
\hline
\end{tabular}

Selanjutnya dilakukan observasi terhadap hasil tes belajar siswa berupa hasil jawaban siswa terhadap soal yang diberikan diakhir pembelajaran

Tabel 4. Hasil Tes Belajar Siswa Pertemuan 5 Siklus II

\begin{tabular}{|l|c|c|c|c|}
\hline \multirow{2}{*}{ No } & \multirow{2}{*}{ Rentang Nilai } & \multicolumn{2}{|c|}{ Pertemuan 5 } & \multirow{2}{*}{ Keterangan } \\
\cline { 3 - 4 } & & F & $\%$ & \\
\hline 1 & $40-49$ & 0 & 0 & \\
\hline 2 & $50-59$ & 0 & 0 & \\
\hline 3 & $60-69$ & 2 & 9.09 & \\
\hline 4 & $70-79$ & 16 & 72.72 & \\
\hline 5 & $80-89$ & 2 & 9.09 & \\
\hline 6 & $90-99$ & 0 & 0 & \\
\hline 7 & $100-109$ & 2 & 9.09 & \\
\hline & JUMLAH & 22 & 100 & \\
\hline & RATA - RATA & \multicolumn{2}{|c|}{73.4} & \\
\hline
\end{tabular}

\section{d. Refleksi}

Berdasarkan hasil observasi melalui instrumen atau format observasi tentang kegiatan pembelajaran dan kegiatan siswa serta tes hasil belajar siswa dalam pertemuan ke 4 dan 5 pada Siklus II, maka dapat direfleksikan sebagai berikut:

1) Kegiatan pembelajaran yang dilaksanakan oleh guru relatif sudah mencapai hasil yang maksimal. Hasil ini dapat dilihat pada tabel kegiatan guru mengajar pada pertemuan 4 dan 5 untuk semua aspek pembelajaran sudah dilaksanakan 100\%, pada pertemuan 5 memperoleh skor akhir 84 (predikat sangat baik).

2) Aktivitas siswa saat belajar pada pertemuan 4 dan 5 menunjukkan adanya peningkatan yang cukup siginifikan. Pada pertemuan 4 memperoleh nilai 62,4 meningkat menjadi 74,85 pada pertemuan 
Meningkatkan Hasil Belajar Kelas VII - C Soal Cerita Metematika Melalui Penggunaan Bahan Manipulatif Siswa Tunagrahita Ringan Di SMPLB Keraton Martapura Kabupaten Banjar

5, hal ini diduga karena guru sudah melibatkan dan memberi kesempatan kepada siswa untuk menggunakan bahan manipulatif.

3) Kegiatan siswa berdasarkan tes akhir pembelajaran pada pertemuan 4 dilihat dari rata-rata kelas (69.78) belum tuntas karena belum memenuhi indikator ketuntasan belajar Matematika yakni 70. Hal itu disebabkan karena beberapa anak masih mendapatkan nilai pada rentangan nilai 50 - 59 sebanyak 1 anak (4.55\%), sedangkan pada rentang nilai 60 - 69 sebanyak 8 orang (36.36\%). Sehingga jika dikalkulasi anak yang tidak tuntas pada pertemuan 4 ini sejumlah 9 atau sekitar $40.9 \%$.

Selanjutnya perbandingan hasil kegiatan guru mengajar antara siklus I dan siklus II menunjukkan peningkatan yang cukup signifikan untuk masing-masing aspek pembelajaran yang dilaksanakan. Peningkatan tersebut dapat dilihat pada skor akhir pertemuan masingmasing siklus yaitu pertemuan 3 (siklus I) memperoleh skor 59 dan pertemuan 5 (siklus II) memperoleh skor 84.

Data perbandingan kegiatan belajar siswa berupa aktivitas belajar pada siklus I dan siklus II dapat dilihat pada tabel 5 berikut ini :

Tabel 5 Perbandingan Aktivitas Belajar Siswa Siklus I dan II

\begin{tabular}{|c|c|c|c|c|c|c|}
\hline \multirow{2}{*}{ No } & \multirow{2}{*}{$\begin{array}{c}\text { Rentang } \\
\text { Perolehan }\end{array}$} & \multicolumn{3}{|c|}{ SIKLUS I } & \multicolumn{2}{c|}{ SIKLUS II } \\
\cline { 3 - 7 } & & \multicolumn{3}{|c|}{ Pertemuan } & \multicolumn{2}{c|}{ Pertemuan } \\
\cline { 3 - 7 } & 1 & 2 & 3 & 4 & 5 \\
\hline 1 & $1-20$ & & & & & \\
\hline 2 & $21-40$ & 40,27 & & & & \\
\hline 3 & $41-60$ & & 42,87 & 50,79 & & \\
\hline 4 & $61-80$ & & & & 62,4 & 74,85 \\
\hline 5 & $81-100$ & & & & & \\
\hline & RATA - RATA & \multicolumn{3}{|c|}{44,64} & \multicolumn{3}{c|}{68,63} \\
\hline
\end{tabular}


Sugiyana

\section{Kesimpulan}

Berdasarkan pengolahan data, mulai dari proses analisa terhadap data dalam penelitian ini yang berhasil dikumpulkan, dan selanjutnya dilakukan proses pengolahan data, serta telah dilakukan interpretasi terhadap hasil-hasil proses tersebut, maka dapat disimpulkan bahwa dengan menggunakan bahan manipulatif dalam pembelajaran matematika yang dilakukan dalam siklus I dan siklus II dengan 5 kali pertemuan mampu meningkatkan kemampuan guru dalam mengajar, aktivitas siswa dalam belajar dan adanya peningkatan hasil belajar soal cerita matematika pada konsep keliling dan luas bangun datar siswa kelasVIII SMPLB Keraton Martapura.

Hal tersebut bisa dilihat dari persentase pelaksanaan kegiatan guru mengajar pada masing-masing pertemuan mengalami peningkatan. Pertemuan $1=75 \%$, pertemuan $2=80 \%$, pertemuan $3=100 \%$ dan memperoleh skor 59 dengan predikat cukup baik, sedangkan pada pertemuan 5 aspek pembelajaran juga sudah dilaksanakan $100 \%$ dan skor yang diperoleh mengalami peningkatan menjadi 84 dengan predikat sangat baik. Jika dilihat dari aktivitas belajar siswa juga terjadi peningkatan yakni pertemuan $1=40,27$ pertemuan $2=42,87$, pertemuan $3=50,79$, pertemuan $4=62,4$, dan pertemuan $5=74.85$. Selanjutnya peningkatan juga bisa dilihat dari hasil rata-rata tes hasil belajar yang diperoleh siswa pada masing - masing pertemuan yakni pertemuan $1=60.45$, pertemuan 2 $=68.41$, pertemuan $3=69.31$, pertemuan $4=69.78$, dan pertemuan 5 $=73.4$ yang berada di atas nilai rata-rata ketuntasan pembelajaran Matematika yakni 60,0 Akhirnya dengan demikian penggunaan bahan manipulatif dalam pelajaran matematika terbukti mampu meningkatkan hasil belajar soal cerita matematika konsep keliling dan luas bangun persegi panjang siswa kelas VII - C SMPLB Keraton Martapura. 
Meningkatkan Hasil Belajar Kelas VII - C Soal Cerita Metematika Melalui Penggunaan Bahan Manipulatif Siswa Tunagrahita Ringan Di SMPLB Keraton Martapura Kabupaten Banjar

\section{Daftar Pustaka}

Aisyah Nyimas, 2007. Pendekatan Pemecahan Masalah Matematika. Depdiknas. Dirjendikti. Jakarta

Arikunto, Suharsimi. 2007. Penelitian Tindakan Kelas. Bumi Aksara. Jakarta.

Bandi Delphie, 2007. Pembelajaran Anak Tunagrahita, Suatu Pengantar dalam Pendidikan Inklusi. Cetakan kedua. Refika Aditama

BSNP, 2007. Pedoman Pemilihan Bahan Ajar. Depdiknas, Dirjendikdasmen. Direktorat Pembinaan SMP

Cliffs, 2007. Matematika Dasar dan Pra - Aljabar. Pakar Raya. Bandung.

Ngalim, Purwanto, 2007. Psikologi Pendidikan. Rosdakarya. Jakarta.

Rachmayanie, Ririanti. 2007. Bahan Ajar Perkembangan. Diktat Untuk Kalangan Sendiri. PGSD. FKIP. UNLAM. Banjarmasin.

Suharjo, 2005. Peningkatan Kualitas Pembelajaran Soal Cerita Metematika SD Melalui Penggunaan Bahan Manipulatif. Jurnal SD, Tahun 14, No 2 November 2005. http://www.ksdpum.web.id/jurnal/ Matematika.pdf. Diakses tgl 5 Januari 2008.

Undang Undang RI. No: 20 Tahun 2003. Tentang Sistim Pendidikan Nasional, Jakarta : Depdiknas

Yani Ahmad. 2008. Penelitian Tentang Masalah Belajar Yang Di Alami Siswa Kelas VIII SMPN Karang Intan. Skripsi. FKIP Jurusan Bimbingan Konseling UNLAM. Banjarmasin.

Yasin Setiawan, 2008. Terobosan Metode Pengajaran Matematika. http:// www. siaksoft.net. diakses Selasa 3 Pebuari 2009. Raynet. Martapura.

Winardi, 2004. Penelitian Tindakan Kelas. Jakarta : Unversitas Terbuka

\section{Sugiyana}

SMPLB Keraton Martapura

E-mail: Sugiyana@gmail.com 
